\title{
ESTIMATION OF MEDICAL EQUIPMENT PRICES - A CASE STUDY OF TOMOTHERAPY EQUIPMENT IN THE CZECH REPUBLIC
}

\author{
Gleb DONIN ${ }^{1}$, Miroslav BARTÁK ${ }^{2}$, Peter KNEPPO ${ }^{3}$ \\ 1,3 Department of Biomedical Technology, Faculty of Biomedical Engineering, \\ Czech Technical University in Prague, Nám. Sitná 3105, 27201 Kladno, Czech Republic \\ ${ }^{2}$ Department of Social Work, Faculty of Social and Economic Studies, Jan Evangelista Purkyně \\ University in Ústí nad Labem, Moskevská 54, 40096 Ústi nad Labem, Czech Republic \\ E-mails: ${ }^{1}$ gleb.donin@fbmi.cvut.cz (corresponding author); \\ ${ }^{2}$ miroslav.bartak@ujep.cz; ${ }^{3}$ kneppo@fbmi.cvut.cz
}

Received 27 July 2017; accepted 22 November 2017

\begin{abstract}
Medical equipment (ME) is often considered to be an important factor in the growth of healthcare expenditures. In the Czech Republic (CR) validated approach does not yet exist for hospitals to use to assess commercial offers, nor is there a generally accepted methodology for regulatory bodies to allow for the evaluation of the effectiveness of prior purchases. This study intends to present a methodological approach that will allow for assessing the effectiveness of the procurement of capital ME based on international prices. The case of the purchase of tomotherapy system in the CR was used to demonstrate the developed approach. We performed a multiway search for international estimated and exact prices for tomotherapy unit using public-procurement databases, scientific papers, health technology assessment studies, professional reports, and Internet searches. All of the data that was gathered on prices was subjected to critical assessment vis-à-vis the reliability of the information. This research lays new methodology that may provide general background of international comparison studies focused on ME. The results provide support for decision making about the acquisitions of ME.
\end{abstract}

Keywords: tomotherapy, medical equipment, price estimation, price comparison, acquisition, international comparison.

JEL Classification: I10, E31.

\section{Introduction}

Medical equipment is generally considered to be an important factor in the growth of health expenditures (for discussion, see Ivlev et al. 2014). According to the latest available data, health spending is estimated to have increased by 1.0 percent in real terms across the OECD countries in 2013 (OECD 2015). Healthcare systems in the OECD countries thus face acute financial pressure; healthcare providers are responding to this pressure more and more by exploring every opportunity to increase efficiency and to reduce costs (Chilukuri et al. 2012; Gavurova, Soltes 2016; Soltes, Gavurova 2015; Maresova et al. 2016). 
The number of large medical devices in the Czech Republic (CR) has increased greatly over the last decade (IHIS 2013). For example, at the end of 2011 there were 155 computed tomography scanners in the CR. Since 2001 the number of such devices per million inhabitants increased by 29 per cent, rising from 11.4 to 14.8 . The number of magnetic resonance imaging (MRI) scanners gradually grew from 19 in 2001 to 72 in 2011 (the number per million inhabitants increased from 1.9 in 2001 to 6.9 in 2011). In comparison with other Vysegrád group countries the CR is comparatively well equipped with large medical devices such as diagnostic imaging technologies (Alexa et al. 2015). Because large medical devices are usually not manufactured in the CR, they must be imported, either from within or outside the European Union (EU). Since the CR predominantly has a publicly funded healthcare system, both the purchase and reimbursement of these medical devices are mainly covered by public sources (e.g. public health insurance and public budgets). This implies the need for both the cost-effective use of public funding and the effective use of public procurements, where price is most important criterion (Roubinek et al. 2015). The previous decade was also characterized by the possibility of using EU structural funding to purchase new medical devices. Unfortunately, one aspect of the many purchases that have been made in the CR is the suspicion that these purchases have been overpriced in some cases (Transparency International - Czech Republic 2007). The Czech courts have examined a few of the purchases, after which several managers faced accusations related to their medical device purchases (e.g. Bachorík 2016). The Ministry of Finance of the CR (2014) also expressed doubts about the purchases of some of the devices that had been financed by EU structural funds. Another feature that may be observed in the field of medical device costs is that the doctors involved often have little or no idea how much medical devices cost (Okike et al. 2014), both in terms of purchases and operational costs.

The goal of this study is to suggest a possible approach for medical equipment price estimation based on international prices, as well as the approach's utilization in the case of procurement of the first TomoTherapy ${ }^{\circledR}$ in the CR. General University Hospital in Prague was planning acquisition of the first tomotherapy system in CR since 2013. Tomotherapy equipment is one of the latest modalities in radiotherapy, in which irradiation is carried out by a helical tomotherapy technique (Van Dyk et al. 2002). The radiation source (linear accelerator) moves around the patient along a spiral trajectory using an on-board computed tomography (CT) scanner for imaging purposes. Tomotherapy equipment can deliver better conformity of dose distribution in comparison with standard devices for 3D-conformal radiotherapy and intensity-modulated radiotherapy (Hsieh et al. 2012; Mesbah et al. 2011; NHSC 2006; Tsai et al. 2011). Tomotherapy units are suitable for the irradiation of a wide range of tumours from head to toe and, in certain cases, they can also be used for stereotactic irradiation (Ballini et al. 2010; Gerrity et al. 2012; Ministry of Health Malaysia 2006; Van Dyk et al. 2002; Yartsev et al. 2007).

\section{Literature review}

Prices for medical equipment differ around the world for many reasons, including differences in customs settings, market restrictions, and innovations, as well as further development of the devices or in the healthcare system itself (Szabo, Sidor 2014; Sol- 
tes, Gavurova 2014; Gavurova, Vagasova 2016). One important step during international price comparisons involves the selection of comparable items. Drug products, for example, may be easily compared and identified using chemical formulas, although dissimilarities in package sizes between countries remains a problem (Andersson 1993). Medical equipment is characterized by a high level of technical complexity that creates variability in a number of components. In the case of sophisticated medical equipment such as CT or MRI devices, virtually no two similar devices exist; they may vary in terms of accessories and additional components, software and settings, installation locations, and the configuration of the place of operation. This situation makes any medical equipment purchase even more complicated to evaluate in terms of conducting price comparisons. The market for medical equipment within developed countries may almost be considered a business-to-business market, where prices are often negotiated. The result of such a market is that different buyers pay substantially different prices for the same product, even when it comes from the same supplier (Grennan 2013).

International price comparisons for medical products are common within the health economics field (Danzon, Furukawa 2008; Hinsch et al. 2014; Simoens 2007; Vogler et al. 2015); reference pricing, however, is still very rare in the medical-devices sector (Sorenson, Kanavos 2011). Based on the empirical research and literature review we have conducted, we have identified several methodological issues in the process of conducting price estimations for medical equipment.

\subsection{Information sources}

The first step in this process is to gather information about medical equipment prices from other nations. Because final market prices are tend to be a commercial secret, the necessary data can be difficult to locate. Regardless of the information quality and reliability (i.e., trustfulness), the researcher has to identify all available data that incorporates prices for the medical equipment model. It is possible to use different information sources, such as public-procurement databases, sales contracts (purchase orders), price quotes from sellers, price lists from manufacturers and distributors, scientific publications, health technology assessment (HTA) studies, reports from professional medical societies and other experts, and general news and Internet discussions. The information sources vary in terms of public availability, as well as reliability and temporal availability.

Public-procurement databases contain information about ongoing and completed tenders. In the EU, for example, public organizations are governed by local public-procurement acts. Specific types of tender-related information on such procurements have to be published in an EU-wide database known as the "Tenders Electronic Daily" (TED) database (European Union 2017). Among other data, TED database contains information related to the results of public tenders: descriptions of purchased products, buyers, and suppliers; final achieved prices and related taxes. Due to the legislative basis of this information source, the reliability of the data may be considered to be quite high.

Some countries, including the CR, oblige certain public organizations to publish the results of any procurement above specified limits in the form of electronic copies of sales contracts. Sales contracts often contain more information than public-procurement 
databases do, but finding and understanding the terms and conditions of contracts from other countries can be a challenge. Because such data does represent the real-world prices of medical equipment combined with contract terms and conditions, such sources thus need to be taken into account whenever they are available. Contracts that define future prices as an agreement between buyer and seller in which the conditions are set in place for the procurement of selected models for specified periods may also provide information about suggested future prices.

Scientific publications, HTA studies, and reports from professional medical societies and experts on medical equipment often contain data about acquisition costs. Although such prices represent the average costs for given models of medical equipment, the studies' authors generally estimate the prices based on the available data; news gathered from hospital websites or other media may also contain information about medical equipment prices. News reports that acknowledge the purchase of medical equipment often include the whole capital costs of acquisition but do not specify further details. Such sources may be used as additional reference sources during the price-estimation process.

\subsection{Country-specific data}

For this study, we will reference the pricing information that we obtained from different countries with different settings. Diversity in healthcare-system models (e.g. Bismarck, Beveridge, National Health Insurance, Out-of-Pocket Models) or healthcare-facility type (private or public) both influence the way in which medical equipment is funded and procured and therefore affects final price (Graves 2011). Market characteristics - especially the level of competition between distributors - also affect procurement costs (Pammolli et al. 2005). Because the regulation of medical devices and related costs varies among different countries (Kaplan et al. 2004; Kramer et al. 2012; Sorenson, Drummond 2014), manufacturers and distributors may use these variances to adjust medical equipment prices. Another factor that affects the pricing of medical equipment is variations in taxes and import duties in different countries.

The price levels for specific products also vary among different countries due to manufacturers' pricing strategies. Deloitte's study (2012), for instance, pointed out that many companies in the medical-devices market do not use global pricing contracts (i.e., one price for each product worldwide); instead, they are focused on local markets based on local demands, competition, and negotiation power.

To reduce possible errors during the gathering of international data, the comparison must focus on countries that are similar, within parameters related to equipment-funding types, market structure, and regulatory approach. We should point out, however, that differences in country-specific parameters are expected to affect the validity of such pricing data.

\subsection{Limitations of price data}

Various types of prices are available in the information sources mentioned above, including list price, sale price, and others. While conducting research, it is necessary to determine the price that is appropriate for estimation purposes. The use of list pric- 
es may lead to overestimation of a medical device's real price (Graboyes 1994). The healthcare sector, especially in the United States, is characterized by the widespread use of discounts that sellers provide to hospitals based on negotiations (Lerner 2010). As an example, the pricing list in the purchasing memorandum between New York State and one of the world largest manufacturers of medical equipment contains suggested net prices for diagnostic-imaging equipment that are 40 percent lower on average than the list prices (New York State Procurement). For these reasons, it is best to focus on the sale prices (i.e., the final prices in contracts) that were actually abided by within the acquisitions.

Medical equipment price may or may not include taxes, depending on the origin of the information source. The taxation systems and types of taxes (e.g., sales taxes or valueadded taxes [VAT]) that are applied to medical equipment differ around the world; for example, the standard VAT rate varies between 17 and 27 percent within the EU. For this reason, price comparisons must be provided in net-of-tax prices to avoid any possible discrepancies caused by different tax rates. The use of sources that are in any way unreliable could generate doubt about whether or not the price contains specific taxes. These kinds of situations must be resolved based on experts' assumptions, which have to be clarified while conducting research.

Each final price may include separate components, such as the price of the item itself, the price of any additional components and accessories, user training and installation costs, software supplied with the equipment, shipping costs, additional services (i.e., maintenance), consumables, and others. Such price components for medical equipment may contain a significant part of the equipment's total price. To cite two examples, one probe for a diagnostic ultrasound unit may represent 20 percent of the unit price itself, while prices for additional annual maintenance contracts for radiotherapy equipment are estimated to represent up to 10 percent of equipment costs (NICE 2014). These factors must be taken into account while conducting pricing analyses.

\subsection{Temporal price conversion}

Any pricing data that is collected may be related to different time periods. The difficulty in determining temporal price changes exists for all types of products and services, including new products and technologies that are widely introduced in the healthcare sector (Graboyes 1994). Different countries have developed individual pricing indices, each based on a predefined sector of products or services. The best-known index is the consumer price index (CPI), which is focused on a basket of products and services purchased by households. The healthcare market utilizes other price indices, such as the medical care price index, the personal healthcare expenditures deflator, and the national health expenditures deflator, to name a few.

Some of the most commonly used price indices that may be used during the estimation of price of medical equipment include the following:

- Gross domestic product (GDP) deflator: a general measure of inflation.

- Consumer price index (CPI): a general price deflator from international statistical sources (e.g., OECD 2017a; World Bank 2017b) based on national CPIs as pub- 
lished by each country. This index could be stated for different commodities (all goods, food, energy, etc.).

- Harmonized index of consumer prices (HICP): a comparable measure of inflation in EU and other countries. This index is published by Eurostat (Eurostat 2017a); the index is available for a vast range of different commodities, including such groups of goods as "Medical products, appliances and equipment".

Donahoe and King (2015) demonstrated that price indices for medical devices (for example in the United States) are much lower than with other indices, such as the medical consumer price index or overall CPI. According to their analysis, the average annual rate for medical-device prices during the period 1989-2013 was relatively small: only 0.9 percent. Prices for medical devices, however, are commonly discounted in economic analyses using CPIs for the given country (Brown et al. 2008; Brown et al. 2007a, 2007b; Long et al. 2013). It is thus possible to use the CPI as an upper boundary for changes in pricing levels for medical devices.

Prices for healthcare technologies (i.e., medical devices) are also influenced by the effects of "experience curve," where the price is related to total production volume (Brown et al. 2007b). Studies have shown that the experience curve for medical devices could follow a two-phase curve, and that the number of years since regulatory approval is the most significant factor in correlations with the experience-curve slope (Brown et al. 2008, 2007a). Brown et al. (2007a) also showed, however, that medical equipment (such as image-guided surgery hardware) experiences relatively lower price-decline rates than smaller medical devices such as stents or defibrillators. One possible reason for this is that medical devices are generally characterized by slower price-decline rates in the early stages of their lifecycles, possibly because of a lack of competition (Brown et al. 2007b). For the purposes of estimation, during the early stages of the lifecycle of a medical device it is thus possible to assume that unit price will be nearly stable and that the pricing trend will be affected by inflation.

\subsection{Price conversion between countries}

Prices vary not only temporally but also between countries due to different pricing levels -even among countries that use the same currency, such as Belgium and Portugal (Vachris, Thomas 1999). Several methods may be used to convert prices between different countries and currencies, such as international comparisons by fixed-exchange currency rates and the use of purchasing power parity (PPP) for conversion prices from one currency to another.

Conversion via official exchange rates is common in international price comparisons, although currencies' exchange rates are influenced by other factors than simply the price level within different countries. Exchange rates do not reflect objective differences in prices between countries; the rates instead reflect a degree of interest in the currencies used in international markets. The official average exchange rates published by Eurostat or local central banks could be used for pricing estimation.

Another way to achieve pricing comparisons is to use PPP, which represents the number of units of a given national currency for which one can buy the same amount of goods 
and services in the national market as a unit of another currency could purchase in another market. This approach is standard for health-expenditures comparisons (Willemé, Dumont 2014). PPP is based on complex international comparison projects of different consumer baskets. The OECD and Eurostat have conducted several studies in this field since the early 1980 s to take the relative purchasing powers of the currencies of individual EU and OECD member countries into account. The OECD statistical database provides data on general PPP for GDP on a regular basis (OECD 2017c). Eurostat provides a more detailed view of this indicator, including PPP for several aggregates, expenditure categories, and GDP groups (Eurostat 2017b). Detailed PPP data is available for the expenditure class "Electrical and optical equipment," which covers medical equipment (OECD/Eurostat 2012).

\subsection{Experts' judgment}

The final aggregation of processed data should lead to a formalized price estimation. Expert judgment is a common and acknowledged approach for generating price estimates based on experts' background, skills, and collected data related to the subject. In everyday life, expertise and decision-making are inseparably enmeshed. With the exception of purely psychomotor areas, we expect that widely identified experts will also make good judgments and decisions within their domain of expertise (Herbig, Glöckner 2009). This approach makes it possible to carry out short-term estimations. In comparison to other estimation techniques (e.g., hedonic price estimation or knowledge-based systems), this approach requires relatively few resources in terms of time, cost, and data. A cost estimate is often needed before the procurement process begins. However, there is not enough time or space to develop complex deterministic or other pricing models for specified medical devices.

The expert-judgment approach is used within the health sector for both clinical and nonclinical decision-making activities. When addressing difficult multidisciplinary problems such as the purchase of tomotherapy system, a combination of knowledge from several experts is required, especially from experts in various fields (Ivlev et al. 2015). This paper takes the knowledge summarized by Ivlev et al. (2015) into consideration; the goal is to conduct a complex assessment of the gathered data and to tap into various experts' knowledge.

\section{Methodology}

Based on a comprehensive literature review, we used the following approaches for medical-equipment price estimation based on international prices in the case of tomotherapy system in the CR for General University Hospital in Prague in 2013.

We conducted a multiway (multifaceted) search for international estimated and exact prices of selected medical equipment. The TED database was used as the main information source for exact prices (sale prices) in the EU. The keyword tomotherapy (and its translations into key European languages, such as tomothérapie in French or tomoterapia in Polish) was used for the search. 
We then conducted a literature review in order to identify prices for tomotherapy equipment in various countries; we limited the review to the following database systems: the Web of Science (WOS), ScienceDirect (Elsevier), SpringerLink, Wiley Online Library, PubMed, and Google Scholar. We used the keyword tomotherapy, and we included English-language studies in the review. We reviewed the full texts of papers to gather information about tomotherapy capital costs.

In addition to previous results, we also investigated HTA studies and reports from professional medical societies and experts on medical equipment, including published reports and studies by organizations such as the ECRI Institute (USA), NICE (UK), EUnetHTA (EU), ISPOR (multiple countries), and others. Finally, we conducted a basic Internet search using the English, German and Italian translations of keywords such as tomotherapy, price, or cost. The Internet search focused on news articles about realized procurements of such equipment around the world, as well as on other professional reports that were not found during the previous search phase.

All of the data that was gathered on estimated prices was then subjected to critical assessment in terms of reliability and the trustworthiness of information. We found the price information that we had obtained from HTA studies and professional reports to be reliable data for reference; we also considered news articles from hospital websites to be credible sources. Other data that had been gathered was subjected to detailed analysis; in the case of significant risk of bias, this data was excluded from the study. Any potential uncertainties in the credibility of the source of the information were clearly set forth for further assessment. We analyzed the applicability (suitability) of the data we had gathered; this analysis focused on determining if purchased tomotherapy equipment corresponded to the objective. In other words, we analyzed the Tomotherapy model unit, as well as its accessories, terms, and the conditions of contractual and price components, in order to ensure the comparability of the price data that was included.

After conducting a critical assessment and exclusion of irrelevant and/or unreliable information, we performed an adjustment of temporally related national data. The pricing data collected for each procurement was inflated according to the country of origin, based on inflation indices of credible international statistical organizations. For the pricing data from EU member nations, we used the harmonized index of consumer prices (HICP) from Eurostat, and the index for category "Medical products, appliances and equipment" (Eurostat 2017a). For non-EU countries that are members of the OECD, we used the CPI from the OECD statistics and the index for items in the "non-food, nonenergy" category (OECD 2017b). For other countries, we used the GDP deflator from the World Bank (World Bank 2017a). The result of the adjustment was a broad range that represented the unification of these three estimates.

The price interval we obtained in the previous stage was then adjusted for national data so that we could make international comparisons. The collected price data for each procurement was adjusted according to the country of origin, based on (I) official exchange rates (CNB 2017) and (ii) PPP, based on Eurostat PPP data for electrical and optical equipment (Eurostat 2017b). 
Finally, we located the adjusted price data in the form of price intervals for each procurement; we then used this data in combination with the results of the critical assessment of the information sources that had been provided to a panel of experts. The experts' information, which was based on data they had received, their knowledge of market characteristics in the CR, and the demands of Czech purchasers (General University Hospital in Prague), was then used to estimate the proposed price range for capital costs of a tomotherapy unit within local conditions.

\section{Results}

According to the suggested methodology of the study, a search was conducted in the TED database for the procurement of tomotherapy units; the results are represented in Table 1. During our assessment of the applicability of the pricing data, we excluded the procurement by Azienda Ospedaliera Spedali Civili Di Brescia in Italy from 2011, because the final price included an additional eight-year service contract, and there was not enough data to separate the equipment price.

Table 1. Price information for tomotherapy units obtained from public-procurement databases

\begin{tabular}{|c|c|c|c|c|c|}
\hline Year & Country & Buyer & Currency & $\begin{array}{l}\text { Price without } \\
\text { taxes }\end{array}$ & Supplier \\
\hline 2013 & France & $\begin{array}{l}\text { CHU de Martinique } \\
\text { (CHU de Fort-de-France) }\end{array}$ & EUR & 3955663 & $\begin{array}{l}\text { TomoTherapy } \\
\text { Europe GmbH; Zug, } \\
\text { Switzerland }\end{array}$ \\
\hline 2011 & Italy & $\begin{array}{l}\text { Azienda Ospedaliero- } \\
\text { Universitaria Ospedali Riuniti }\end{array}$ & EUR & 4113000 & $\begin{array}{l}\text { Tecnologie Avanzate } \\
\text { TA SRL; Turín, Italy }\end{array}$ \\
\hline 2011 & Poland & $\begin{array}{l}\text { Centrum Onkologii-Instytut } \\
\text { im. Marii Skłodowskiej-Curie } \\
\text { Oddział w Gliwicach }\end{array}$ & PLN & 15740602 & $\begin{array}{l}\text { EDO MED Sp.; } \\
\text { Warsaw, Poland }\end{array}$ \\
\hline 2011 & Italy & $\begin{array}{l}\text { Azienda Ospedaliera Spedali } \\
\text { Civili Di Brescia* }\end{array}$ & EUR & 14371200 & $\begin{array}{l}\text { Medipass SpA; } \\
\text { Bologna, Italy }\end{array}$ \\
\hline 2011 & Finland & IS-Hankinta Oy & EUR & 3210000 & $\begin{array}{l}\text { Accuray Europe } \\
\text { SAS; Paris, France }\end{array}$ \\
\hline 2010 & France & $\begin{array}{l}\text { Assistance publique-Hôpitaux } \\
\text { de Paris }\end{array}$ & EUR & 3256710 & $\begin{array}{l}\text { TomoTherapy Inc.; } \\
\text { Madison, WI, USA }\end{array}$ \\
\hline
\end{tabular}

Note: * Data excluded because the final price included an additional eight-year service contract and construction work; its data thus could not be separated from the price of the equipment.

Source: authors' own processing according to the TED database (European Union 2017).

Our systematic search within scientific papers was unable to identify information about tomotherapy equipment prices, which supports our statement that all information about final procurement prices remains hidden. During our search for HTA studies, professional reports, and news articles, we identified the estimated prices for tomotherapy units, as shown in Table 2. 
Table 2. Other data on estimated prices of tomotherapy units

\begin{tabular}{lllccc}
\hline Year & Country & Source & Currency & Price & Type \\
\hline 2012 & Italy & (Giornale di Sicilia 2012) & EUR & 4700000 & News \\
\hline 2012 & Sri Lanka & (DailyFT 2012) & USD & 3725000 & News \\
\hline 2008 & Italy & (L'Azienda Ospedaliera 2008) & EUR & 3500000 & News \\
\hline 2008 & Singapore & (Singapore Medicine 2008) & USD & 4000000 & News \\
\hline 2007 & USA & (AUTM 2007) & USD & 3500000 & Report \\
\hline 2006 & UK & (NHSC 2006) & GBP & 2000000 & Report \\
\hline 2005 & Australia & (ANZHSN 2009) & AUD & 5500000 & Report \\
\hline
\end{tabular}

Source: authors' own processing based on literature review.

According to the suggested methodology of our study, we conducted three methods of inflation adjustment: (i) using the GDP deflator; (ii) adjustment for EU countries via HICP, and for other countries via general CPI; and (iii) adjustment for all countries via CPI. The result was a broad range that represents the unification of these three estimates.

Table 3. Inflation-adjusted prices for tomotherapy units from public-procurement databases

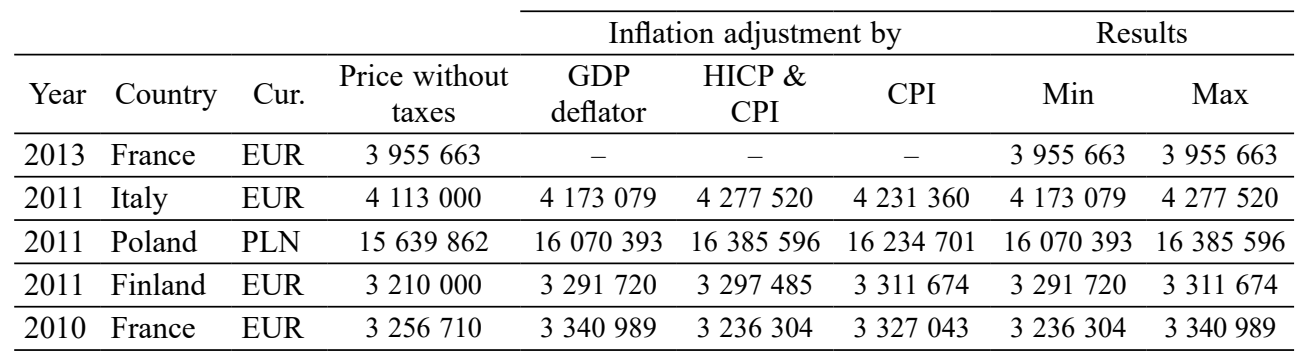

Note: GDP deflator: complex inflation indicator (World Bank 2017a); HICP: harmonized index of consumer prices for category "Medical products, appliances and equipment" (Eurostat 2017a); CPI: Consumer prices index for category "non-food and non-energy" (OECD 2017b). Inflation adjustment for France 2013 was not carried out due to the year of acquisition.

Source: authors' own calculations.

Table 4. Inflation adjustment of estimated prices for tomotherapy units

\begin{tabular}{lllccccccc}
\cline { 4 - 9 } Year & \multirow{2}{*}{ Country } & \multirow{2}{*}{ Cur. } & \multirow{2}{*}{ Price } & $\begin{array}{c}\text { GDP } \\
\text { deflator }\end{array}$ & $\begin{array}{c}\text { HICP \& } \\
\text { CPI }\end{array}$ & CPI & Min & \multirow{2}{*}{ Max } \\
\hline 2012 & Italy & EUR & 4700000 & 4700126 & 4796432 & 4762445 & 4700126 & 4796432 \\
\hline 2012 & Sri Lanka & USD & 3725000 & 3725065 & - & - & 3725000 & 3725065 \\
\hline 2008 & Italy & EUR & 3500000 & 3678144 & 4044444 & 3788079 & 3678144 & 4044444 \\
\hline 2008 & Singapore & USD & 4000000 & 4206208 & - & - & 4000000 & 4206208 \\
\hline 2007 & USA & USD & 3500000 & 3794256 & 3883699 & 3883699 & 3794256 & 3883699 \\
\hline 2006 & UK & GBP & 2000000 & 2254426 & 2136683 & 2325765 & 2136683 & 2325765 \\
\hline
\end{tabular}

Note: GDP deflator: complex inflation indicator (World Bank 2017a); HICP: harmonized index of consumer prices for category "Medical products, appliances and equipment" (Eurostat 2017a); CPI: Consumer prices index for category "non-food and non-energy" (OECD 2017b). Conversion by HICP and CPI for Sri Lanka and Singapore was not carried out due to lack of official Eurostat and OECD data. Source: authors' own calculations. 
The two approaches were used to convert prices from other currencies into CZK: (i) by using official exchange rates (CNB 2017) and (ii) using PPP; this assessment was based on Eurostat PPP data for electrical and optical equipment (Eurostat 2017b).

Table 5. Conversion prices to CZK according to exchange rates and PPPs

\begin{tabular}{|c|c|c|c|c|c|c|c|}
\hline \multirow[b]{3}{*}{ Country } & \multirow[b]{3}{*}{ Cur. } & & & \multicolumn{4}{|c|}{ Price in $\mathrm{CZK}$} \\
\hline & & \multicolumn{2}{|c|}{ Inflation-adjusted price } & \multicolumn{2}{|c|}{ By exchange rate } & \multicolumn{2}{|c|}{ By PPP } \\
\hline & & Min & $\operatorname{Max}$ & Min & $\operatorname{Max}$ & Min & $\operatorname{Max}$ \\
\hline $\begin{array}{l}2013 \\
\text { France }\end{array}$ & EUR & 3955663 & 3955663 & 100770507 & 102625712 & 100698827 & 100698827 \\
\hline $\begin{array}{l}2011 \\
\text { Italy }\end{array}$ & EUR & 4173079 & 4277520 & 106309192 & 110975979 & 105131712 & 107762873 \\
\hline $\begin{array}{l}2011 \\
\text { Poland }\end{array}$ & PLN & 16070393 & 16385596 & 95565553 & 102784860 & 99595069 & 101548513 \\
\hline $\begin{array}{l}2011 \\
\text { Finland }\end{array}$ & EUR & 3291720 & 3311674 & 83856573 & 85918076 & 72746261 & 73187239 \\
\hline $\begin{array}{l}2010 \\
\text { France }\end{array}$ & EUR & 3236304 & 3340989 & 82444838 & 86678616 & 82386194 & 85051151 \\
\hline
\end{tabular}

Note: Maximum and minimum monthly average exchange rates of Czech National Bank (CNB) for 2013 was applied (CNB 2017); PPP: purchasing power parity in "Electrical and optical equipment" for EU nations (Eurostat 2017b).

Source: authors' own calculations.

Table 6. Conversion-estimated prices to CZK according to exchange rates and PPPs

\begin{tabular}{|c|c|c|c|c|c|c|c|}
\hline \multirow[b]{3}{*}{ Country } & \multirow[b]{3}{*}{ Cur. } & & & \multicolumn{4}{|c|}{ Price in $\mathrm{CZK}$} \\
\hline & & \multicolumn{2}{|c|}{ Inflation-adjusted price } & \multicolumn{2}{|c|}{ By exchange rate } & \multicolumn{2}{|c|}{ By PPP } \\
\hline & & Min & Max & Min & $\operatorname{Max}$ & Min & Max \\
\hline $\begin{array}{l}2012 \\
\text { Italy }\end{array}$ & EUR & 4700126 & 4796432 & 119735706 & 124438626 & 118409514 & 120835733 \\
\hline $\begin{array}{l}2012 \\
\text { Sri Lanka }\end{array}$ & USD & 3725000 & 3725065 & 71034041 & 74547277 & - & - \\
\hline $\begin{array}{l}2008 \\
\text { Italy }\end{array}$ & EUR & 3678144 & 4044444 & 93700721 & 104929067 & 92662892 & 101891038 \\
\hline $\begin{array}{l}2008 \\
\text { Singapore }\end{array}$ & USD & 4000000 & 4206208 & 76278165 & 84176081 & - & - \\
\hline $\begin{array}{l}2007 \\
\text { USA }\end{array}$ & USD & 3794256 & 3883699 & 72354724 & 77721907 & 51981310 & 53206673 \\
\hline $\begin{array}{l}2006 \\
\mathrm{UK}\end{array}$ & GBP & 2136683 & 2325765 & 63109577 & 72461780 & $71 \quad 160843$ & 77458083 \\
\hline $\begin{array}{l}\text { Note: Maxi } \\
\text { PPP: purcha } \\
2017 \mathrm{~b} \text { ), and } \\
\text { for Sri Lank }\end{array}$ & $\begin{array}{l}\text { um a } \\
\text { ing } p \\
\text { urch }\end{array}$ & $\begin{array}{l}\text { minimum } \\
\text { er parity fo } \\
\text { ag power } 1 \\
\text { gapore w }\end{array}$ & $\begin{array}{l}\text { nthly ave } \\
\text { ategory "B } \\
\text { ty for GD } \\
\text { ot carried }\end{array}$ & $\begin{array}{l}\text { exchange } \\
\text { orical and op } \\
\text { it due to lack }\end{array}$ & $\begin{array}{l}\text { ates of CNB } \\
\text { tical equipme } \\
\text { tries (OECD } \\
\text { of official OI }\end{array}$ & $\begin{array}{l}\text { were applied } \\
\text { ht" for EU nat } \\
2017 \mathrm{c}) \text {. Conv } \\
\text { CD data. }\end{array}$ & $\begin{array}{l}\text { (CNB 2017) } \\
\text { ions (Eurosta } \\
\text { ersion by PPP }\end{array}$ \\
\hline
\end{tabular}


After the price conversion (adjustment for inflation and differences between countries), the price range for tomotherapy equipment for the CR was estimated to 115-125 million CZK (including VAT) and 95-103 million CZK (without VAT). The price range was estimated by experts based on adjusted price interval. The final price depended on the current CZK exchange rate and other factors (e.g., delivery for any construction work, technology licenses for computer stations, or picture archiving and communication systems [PACSs]). The estimated price does not include any design work or construction work for installing the system. The results of this study in unchanged form were submitted to General University Hospital in Prague at the end of 2013; the procurement of the tomotherapy unit was realized by the same hospital in 2014. The acquisition price for the medical equipment (including installation, training, etc.) was roughly 121 million CZK including VAT, or 100.8 million CZK without VAT. The technical specifications, accessories, and purchase-contract parameters were all standard for this type of medical equipment in the CR.

\section{Discussion}

Medical equipment is generally characterized by rapid improvements in functionality, performance, and safety. Changes in product quality or functionality extension are commonly not covered by price indices (Molina, Christian 2012; Strahl, Sobczak 2017). General price indices focus on consumer expenditures and do not include sales and excise taxes that are part of the price of goods. Industry-price indices that reflect the revenue a producer receives may also be used for price adjustments. The complication is that medical devices are sold in business-to-business markets, where the prices are often negotiated. This can result in different buyers paying substantially different prices for the same product, even when they come from the same supplier (Grennan 2013); price indices are not designed to work with this sort of system. It is also important to mention that our study covers hospitals in the CR that buy medical devices in CZK; limited evidence exists about the exchange that would occur if they received USD or euros from banks, and how they would negotiate such exchanges if they did receive such foreign currencies.

The correction of differences in prices of medical devices between countries is more difficult to accomplish than when treating temporal differences. The discrepancies in pricing for medical devices between countries are caused by different price levels (Lerner 2010), even among countries that use the same currency (Vachris, Thomas 1999). Unlike the temporal point of view, which can be resolved by using different inflation rates, a comparison between countries is more difficult to accomplish. Several methods may be used for price conversion between different countries and currencies. For example, some researchers have conducted international price comparisons of medicaldevice prices using fixed exchange rates (Ide et al. 2007; Kuroda et al. 2003); others have applied PPP to acquire conversion prices for medical devices from one currency to another (Simoens et al. 2009; Yasunaga et al. 2007). Different methods will generate different outcomes. Lorenzoni and Koechlin (2017) recently introduced the international comparison of health prices and newly its evaluation by volumes. They recommended 
the use of health and hospital-specific price levels. Unfortunately, this approach was not focused on medical devices.

It is also important to emphasize that consulting experts' decision-making processes to evaluate pricing information may also have limitations (Castellan 1993; Ivlev et al. 2014, 2015; Rush, Rajkumar 2001). The application of experts' judgments on pricing estimations is related to subjective assessment and thus is prone to bias. It is a common approach, however, when examining future medical equipment procurements.

\section{Conclusions}

In this research the main principles of the estimation of medical equipment prices based on international comparison was presented. This paper lays new methodology that can be generally used for future studies and may provide useful background of international comparison studies focused on ME. The proposed methodology allows the assessment of ME prices a can provide support for national and international decision making about the acquisitions of ME. Calculation have shown how this methodology can be applied in practice of different health care system regardless of the type of healthcare financing (both public and private).

Based on the new proposed methodology, we found that the prices of tomotherapy equipment in different countries varied by as much as $+/-€ 1$ million, and that this also applies to countries that share the same currency. After price conversion (i.e., adjustment for inflation and differences between countries), the price range for tomotherapy equipment for the CR was estimated to be 115-125 million CZK including VAT and 95-103 million CZK without VAT. As of 2017, we know that the final purchase price of tomotherapy system was about 150 million CZK ( $€ 5.5$ million), including the cost of construction work, and that the acquisition price for medical equipment (including installation, training, etc.) was roughly 121 million CZK with VAT, or 100.8 million CZK without VAT. The final price is in the range that we have described above, and therefore may be considered a reasonable price. The overall conclusion seems to be that suggested approach is appropriate for ME price estimation tasks.

Nevertheless, this study does suffer from some limitations. General price indices focus on consumer expenditures and do not include sales and excise taxes. Different methods of price correction between countries may generate different outcomes. Use of experts' evaluation during decision-making processes may also have limitations.

Future research should tackle the identified limitations, especially price indexes and correction of price level between different countries. Finally, looking at another types of costly ME, would also be recommended.

\section{Disclosure statement}

The authors declare that during this research they did not have any competing financial, professional, or personal interests from other parties. 
G. Donin et al. Estimation of medical equipment prices - a case study of tomotherapy equipment ...

\section{Acknowledgements}

The authors would like to express their special appreciation and thanks to the internal and external experts Department of Biomedical Technology of the Faculty of Biomedical Engineering CTU involved in this study.

\section{Contribution}

The authors gratefully acknowledge Dr I. Ivlev for his advice and invaluable editorial comments on the final draft.

\section{References}

Alexa, J.; Rečka, L.; Votapkova, J.; van Ginneken, E.; Spranger, A.; Wittenbecher, F. 2015. Czech Republic: health system review, Health System in Transition 17(5): 1-165.

Andersson, F. 1993. Methodological aspects of international drug price comparisons, PharmacoEconomics 4(4): 247-256. https://doi.org/10.2165/00019053-199304040-00003

ANZHSN. 2009. TomoTherapy HI-ART system radiotherapy planning and treatment for cancer patients [online], [cited 7 July 2017]. Australia and New Zealand Horizon Scanning Network. Available from Internet: http://www.horizonscanning.gov.au/internet/horizon/publishing.nsf/Co ntent/68B1F63984E68993CA2575AD0080F3E2/\$File/PS\%20Update\%20Tomotherapy\%20HIART\%20System.pdf

AUTM. 2007. The better world report part one building a stronger economy: profiles of 25 companies rooted in academic research [online], [cited 7 July 2017]. Association of University Technology Managers. Available from Internet: http://www.betterworldproject.org/BetterWorldProject/media/Better-World-Reports/Documents/AUTM_BWR_2007_Part1_Building_Stronger_ Economy_25_Companies.pdf

Bachorík, J. 2016. Soud znovu projednával údajně předražené zakázky v Krajské zdravotní [The court again discussed the allegedly overpriced contracts in the Krajská zdravotní] [online], [cited 7 July 2017]. Český rozhlas Sever. Available from Internet: http://www.rozhlas.cz/sever/ informacezeseveru/_zprava/soud-znovu-projednaval-udajne-predrazene-zakazky-v-krajske-zdravotni--1597077 (in Czech).

Ballini, L.; Cipriani, F.; Guidi, G.; Giovannini, T.; Minozzi, S.; Negro, A.; Pertile, P.; Pirini, G.; Stivanello, E.; Trisolini, R. 2010. Dossier n. 199/2010 - Innovative radiation treatment in cancer: IGRT/IMRT [online], [cited 7 July 2017]. Agenzia sanitaria e sociale regionale dell'EmiliaRomagna. Available from Internet: http://assr.regione.emilia-romagna.it/it/servizi/pubblicazioni/ dossier/doss 199

Brown, A.; Meenan, B. J.; Dixon, D.; Young, T. P. 2008. Application of the experience curve to price trends in medical devices: implications for product development and marketing. Journal of Medical Marketing 8(3): 241-255. https://doi.org/10.1057/jmm.2008.7

Brown, A.; Meenan, B. J.; Young, T. P. 2007a. Marketing innovation: medical device prices follow the experience curve, Journal of Medical Marketing 7(3): 203-212.

https://doi.org/10.1057/palgrave.jmm.5050086

Brown, A.; Meenan, B. J.; Young, T. P. 2007b. Price trend analysis and its implications for the development of new medical technologies, in $29^{\text {th }}$ Annual International Conference of the IEEE Engineering in Medicine and Biology Society, 22-26 August 2007, Lyon, France.

Castellan, N. J. (Ed.). 1993. Individual and group decision making: current issues. Hillsdale, New Jersey: Lawrence Erlbaum Associates. 
Chilukuri, S.; Gordon, M.; Musso, C. 2012. Design to value in medical devices [online], [cited 7 July 2017]. McKinsey \& Company. Available from Internet: http://www.mckinsey.com/ /media/ mckinsey/dotcom/client_service/pharma and medical products/pmp new/pdfs/774172_design_to_ value_in_medical_devices1.ashx

CNB. 2017. Central Bank Exchange Rate Fixing [online], [cited 7 July 2017]. Czech National Bank. Available from Internet: http://www.cnb.cz/en/financial_markets/foreign_exchange_market/exchange_rate_fixing/

Daily, F. T. 2012. Ceylinco healthcare to import Sri Lanka's first TomoTherapy treatment system [online], [cited 7 July 2017]. Available from Internet: http://www.ft.lk/2012/10/23/ceylincohealthcare-to-import-sri-lankas-first-tomotherapy-treatment-system/

Danzon, P. M.; Furukawa, M. F. 2008. International prices and availability of pharmaceuticals in 2005, Health Affairs 27(1): 221-233. https://doi.org/10.1377/hlthaff.27.1.221

Deloitte. 2012. Global pricing survey: managing global pricing excellence [online], [cited 7 July 2017]. Available from Internet: http://www2.deloitte.com/content/dam/Deloitte/de/Documents/ strategy/C-studie-b2b-pricing_122012.pdf

Donahoe, G.; King, G. 2015. Estimates of medical device spending in the United States [online], [cited 7 July 2017]. Available from Internet: https://www.advamed.org/sites/default/files/ resource/994_100515_guy_king_report_2015_final.pdf

European Union. 2017. TED Tenders Electronic Daily [online], [cited 7 July 2017]. Available from Internet: http://ted.europa.eu/TED/main/HomePage.do

Eurostat. 2017a. HICP $(2005=100)$ - Annual Data (average index and rate of change) [online], [cited 7 July 2017]. Available from Internet: http://appsso.eurostat.ec.europa.eu/nui/show. do?dataset=prc_hicp_aind\&lang=en

Eurostat. 2017b. Purchasing power parities (PPPS), price level indices and real expenditures for ESA2010 aggregates [online], [cited 7 July 2017]. Available from Internet: http://appsso.eurostat. ec.europa.eu/nui/show.do?dataset=prc_ppp_ind\&lang=en

Gavurova, B.; Soltes, M. 2016. System of day surgery in Slovakia: analysis of pediatric day surgery discrepancies in the regions and their importance in strategy of its development, $E \& M$ Ekonomie a Management 19(1): 74-92. https://doi.org/10.15240/tul/001/2016-1-006

Gavurova, B.; Vagasova, T. 2016. Regional differences of standardised mortality rates for ischemic heart diseases in the Slovak Republic for the period 1996-2013 in the context of income inequality, Health Economics Review 6(1): 21. https://doi.org/10.1186/s13561-016-0099-1

Gerrity, M.; Thielke, A.; Leof, A. W.; Ryan, K.; Little, A.; Kriz, H.; King, V. 2012. Stereotactic radiosurgery and stereotactic body radiation therapy. Portland, OR: Center for Evidence-based Policy, Oregon Health and Science University.

Giornale di Sicilia. 2012. Palermo, al Civico nuova tomoterapia contro i tumori [online], [cited 7 July 2017]. Available from Internet: http://www.gds.it/gds/sezioni/medicina/dettaglio/articolo/ gdsid/227841/

Graboyes, R. F. 1994. Medical care price indexes, FRB Richmond Economic Quarterly 80(4): 69-89.

Graves, K. 2011. Global best practices in medical device procurement - a road map to system success, Journal of Medical Marketing 11(2): 101-108.

Grennan, M. 2013. Price discrimination and bargaining: empirical evidence from medical devices, American Economic Review 103(1): 145-177. https://doi.org/10.1257/aer.103.1.145

Herbig, B.; Glöckner, A. 2009. Experts and decision making: first steps towards a unifying theory of decision making in novices, intermediates and experts, MPI Collective Goods Preprint 2.

Hinsch, M.; Kaddar, M.; Schmitt, S. 2014. Enhancing medicine price transparency through price information mechanisms, Globalization and Health 10(1): 34.

https://doi.org/10.1186/1744-8603-10-34 
Hsieh, C.-H.; Shueng, P.-W.; Hsiao, S.-M.; Wei, M.-C.; Wu, W.-Y.; Sun, H.-D.; Tien, H.-J.; Wang, L.-Y.; Hsieh, Y.-P. 2012. Helical tomotherapy provides efficacy similar to that of intensitymodulated radiation therapy with dosimetric benefits for endometrial carcinoma, OncoTargets and Therapy 5: 245-253. https://doi.org/10.2147/OTT.S35958

Ide, H.; Yasunaga, H.; Imamura, T.; Ohe, K. 2007. Price differences between Japan and the US for medical materials and how to reduce them, Health Policy 82(1): 71-77.

https://doi.org/10.1016/j.healthpol.2006.08.003

IHIS. 2013. Overview of medical equipment of health establishments of Czech Republic in years 2006-2011 [online], [cited 7 July 2017]. Institute of Health Information and Statistics of the Czech Republic. Available from Internet: http://www.uzis.cz/en/system/files/ai_2013_10.pdf

Ivlev, I.; Kneppo, P.; Bartak, M. 2014. Multicriteria decision analysis: a multifaceted approach to medical equipment management, Technological and Economic Development of Economy 20(3): 576-589. https://doi.org/10.3846/20294913.2014.943333

Ivlev, I.; Kneppo, P.; Barták, M. 2015. Method for selecting expert groups and determining the importance of experts' judgments for the purpose of managerial decision-making tasks in health system, E\&M Ekonomie a Management 18(2): 57-72. https://doi.org/10.15240/tul/001/2015-2-005

Kaplan, A. V.; Bairn, D. S.; Smith, J. J.; Feigal, D. A.; Simons, M.; Jefferys, D.; Fogarty, T. J.; Kuntz, R. E.; Leon, M. B. 2004. Medical device development from prototype to regulatory approval, Circulation 109(25): 3068-3072. https://doi.org/10.1161/01.CIR.0000134695.65733.64

Kramer, D. B.; Xu, S.; Kesselheim, A. S. 2012. How does medical device regulation perform in the United States and the European union? A systematic review, PLoS Medicine 9(7): e1001276. https://doi.org/10.1371/journal.pmed.1001276

Kuroda, N.; Kobayashi, Y.; Desai, K.; Costantini, C.; Kobayashi, M.; Komuro, I. 2003. Impact of change in the price of percutaneous coronary intervention devices on medical expenses, Circulation Journal 67(7): 576-578. https://doi.org/10.1253/circj.67.576

L'Azienda Ospedaliera. 2008. La Tomotherapy a REGGIO EMILIA - UniCredit e Fondazione Manodori sostengono lo sviluppo dell'Arcispedale [online], [cited 7 July 2017]. Available from Internet: http://www.asmn.re.it/Sezione.jsp?titolo=la tomotherapy a reggio emilia - unicredit e fondazione manodori sostengono lo sviluppo dell'arcispedale\&idSezione=1428

Lerner, J. C. 2010. Medical device prices, in P. L. Young, R. S. Saunders, L. Olsen (Eds.). The healthcare imperative: lowering costs and improving outcomes: workshop series summary, Washington, DC: The National Academies Press.

Long, G.; Mortimer, R.; Sanzenbacher, G. 2013. Recent average price trends for implantable medical devices, 2007-2011 [online], [cited 7 July 2017]. Available from Internet: http:// www.advamed.org/resource-center/recent-average-price-trends-implantable-medical-devices-2007-2011-0

Lorenzoni, L.; Koechlin, F. 2017. International comparisons of health prices and volumes: new findings [online], [cited 7 July 2017]. Available from Internet: http://www.oecd.org/health/healthsystems/International-Comparisons-of-Health-Prices-and-Volumes-New-Findings.pdf

Maresova, P.; Klimová, B.; Valis, M.; Kuca, K.; Mohelska, H. 2016. Treatment cost of Parkinson's disease in Central Europe, E\&M Ekonomie a Management 19(3): 31-39.

https://doi.org/10.15240/tul/001/2016-3-003

Mesbah, L.; Matute, R.; Usychkin, S.; Marrone, I.; Puebla, F.; Mínguez, C.; García, R.; García, G.; Beltrán, C.; Marsiglia, H. 2011. Helical tomotherapy in the treatment of pediatric malignancies: a preliminary report of feasibility and acute toxicity, Radiation Oncology 6(1): 102. https://doi.org/10.1186/1748-717X-6-102

Ministry of Finance of the Czech Republic. 2014. Zpráva o auditu systému (Integrovaný operační program) (Číslo auditu: AO/2014/SM/05-IOP) [System audit report (Integrated Operational Programme) (Audit No. AO/2014/SM/05-IOP)] [online], [cited 7 July 2017]. Available from Inter- 
net: http://www.mfcr.cz/assets/cs/media/Informace-zadost-106_Pr-001_2015-02-16_Info-106-99MF-6907-2015-9002-340IK.pdf (in Czech).

Ministry of Health Malaysi. 2006. Technology review: tomotherapy [online], [cited 5 May 2016]. Available from Internet: http://www.moh.gov.my/attachments/6387.pdf

Molina, B. J.; Christian, A. 2012. The art of finding accurate price indices for high-tech equipment, Journal of State Taxation 30(5): 17-21.

New York State Procurement. n.d. Diagnostic imaging equipment (statewide): contractor pricing [online], [cited 7 July 2017]. Available from Internet: http://www.ogs.ny.gov/purchase/spg/pdfdo cs/1260021862ContractorInfo.pdf

NHSC. 2006. Helical Tomotherapy Hi-ART System for External Cancer Radiotherapy: Horizon Scanning Technology Briefing [online], [cited 7 July 2017]. National Horizon Scanning Centre. Available from Internet: http://www.io.nihr.ac.uk/topics/helical-tomotherapy-hi-arttm-system-forexternal-cancer-radiotherapy/

NICE. 2014. Breast Cancer (Early) - intrabeam radiotherapy system: appraisal consultation document [online], [cited 7 July 2017]. National Institute for Health and Care Excellence. Available from Internet: https://www.nice.org.uk/guidance/gid-tag353/resources/breast-cancer-earlyintrabeam-radiotherapy-system-appraisal-consultation-document

OECD. 2015. Focus on health spending 2015. OECD health statistics [online], [cited 7 July 2017]. Available from Internet: https://www.oecd.org/health/health-systems/Focus-Health-Spending-2015.pdf

OECD. 2017a. Inflation (CPI) [online], [cited 7 July 2017]. Available from Internet: https://doi.org/10.1787/eee82e6e-en

OECD. 2017b. Prices: consumer prices, main economic indicators (database) [online], [cited 7 July 2017]. Available from Internet: https://doi.org/10.1787/data-00047-en

OECD. 2017c. Prices: purchasing power parities for GDP and related indicators, main economic indicators (database) [online], [cited 7 July 2017]. Available from Internet:

https://doi.org/10.1787/data-00608-en

OECD/Eurostat. 2012. Eurostat-OECD methodological manual on purchasing power parities (2012 Edition). Paris: OECD Publishing.

Okike, K.; O’Toole, R. V.; Pollak, A. N.; Bishop, J. A.; McAndrew, C. M.; Mehta, S.; Cross, W. W.; Garrigues, G. E.; Harris, M. B.; Lebrun, C. T. 2014. Survey finds few orthopedic surgeons know. The costs of the devices they implant, Health Affairs 33(1): 103-109.

https://doi.org/10.1377/hlthaff.2013.0453

Pammolli, F.; Riccaboni, M.; Oglialoro, C.; Magazzini, L.; Baio, G.; Salerno, N. 2005. Medical devices competitiveness and impact on public health expenditure [online], [cited 7 July 2017]. Study prepared for DG Enterprise European Commission. Available from Internet: http://www. cermlab.it/wp-content/uploads/cerm/MD_Report.pdf

Roubinek, P.; Kladivo, P.; Halas, M.; Koutsky, J.; Opravil, Z. 2015. Changes in the financing of municipalities and local governments of selected cities: possible effects on disintegration processes and municipal policy, E\&M Ekonomie a Management 18(1): 134-150.

https://doi.org/10.15240/tul/001/2015-1-011

Rush, C.; Rajkumar, R. 2001. Expert judgement in cost estimating: modelling the reasoning process, Concurrent Engineering 9(4): 271-284. https://doi.org/10.1177/1063293X0100900404

Simoens, S. 2007. International comparison of generic medicine prices, Current Medical Research and Opinion 23(11): 2647-54. https://doi.org/10.1185/030079907X233395

Simoens, S.; Guillaume, P.; Moldenaers, I.; Depoorter, A.; De Coster, S.; Van Den Steen, D.; Van de Sande, S.; Debruyne, H.; Ramaekers, D.; Lona, M. 2009. International comparison of orthotic brace prices, European Journal of Health Economics 10(2): 149-155.

https://doi.org/10.1007/s10198-008-0112-7 
SingaporeMedicine. 2008. Singapore Medicine - Singapore Takes Cancer Warfare to New Level with TomoTherapy [online], [cited 7 July 2017]. Available from Internet: http://www.prweb.com/ releases/singapore-medicine/asia-leading-medical-hub/prweb1585104.htm

Soltes, M.; Gavurova, B. 2014. Identification of the functionality level of day surgery in Slovakia, Ekonomicky Casopis 62(10): 1031-1051.

Soltes, M.; Gavurova, B. 2015. Quantification and comparison of avoidable mortality-causal relations and modification of concepts, Technological and Economic Development of Economy 21(6): 917-938. https://doi.org/10.3846/20294913.2015.1106421

Sorenson, C.; Drummond, M. 2014. Improving medical device regulation: the United States and Europe in perspective, Milbank Quarterly 92(1): 114-150.

https://doi.org/10.1111/1468-0009.12043

Sorenson, C.; Kanavos, P. 2011. Medical technology procurement in Europe: a cross-country comparison of current practice and policy, Health Policy 100(1): 43-50.

https://doi.org/10.1016/j.healthpol.2010.08.001

Strahl, D.; Sobczak, R. 2017. Conceptual roots for innovation and innovativeness of the economy in Poland, GeoScape 11(1): 41-51. https://doi.org/10.1515/geosc-2017-0004

Szabo, S.; Sidor, J. 2014. The performance measurement system - potentials and barriers for it implementation in healthcare facilities, Journal of Applied Economic Sciences 9(4): 728-735.

Transparency International - Czech Republic. 2007. Odhad ztrát z titulu netransparentniho a neefektivniho nastaveni systému veřejného zdravotnictví v České republice [The estimation of losses due to non-transparent and inefficient setting of public health system in Czech Republic] [online], [cited 7 July 2017]. Available from Internet: https://www.transparency.cz/wp-content/ uploads/tzdrav_studie02052007.pdf (in Czech).

Tsai, C.-L.; Wu, J.-K.; Chao, H.-L.; Tsai, Y.-C.; Cheng, J. C.-H. 2011. Treatment and dosimetric advantages between VMAT, IMRT, and Helical Tomotherapy in prostate cancer, Medical Dosimetry 36(3): 264-271. https://doi.org/10.1016/j.meddos.2010.05.001

Vachris, M. A.; Thomas, J. 1999. International price comparisons based on purchasing power parity, Monthly Labor Review 122(10): 3-12.

Van Dyk, J.; Kron, T.; Bauman, G.; Battista, J. 2002. Tomotherapy: a "revolution" in radiation therapy, Physics in Canada 58(2): 79-86.

Vogler, S.; Vitry, A.; Babar, Z. U. D. 2015. Cancer drugs in 16 European countries, Australia, and New Zealand: a cross-country price comparison study, The Lancet Oncology 17(1): 39-47. https://doi.org/10.1016/S1470-2045(15)00449-0

Willemé, P.; Dumont, M. 2014. Machines that go "Ping": medical technology and health expenditures in OECD countries, Health Economics 24(8): 1027-1041.

https://doi.org/10.1002/hec.3089

World Bank. 2017a. Inflation, GDP deflator (annual \%) [online], [cited 7 July 2017]. Available from Internet: http://data.worldbank.org/indicator/NY.GDP.DEFL.KD.ZG

World Bank. 2017b. World Development Indicators [online], [cited 7 July 2017]. Available from Internet: http://data.worldbank.org/indicator/FP.CPI.TOTL

Yartsev, S.; Kron, T.; Van Dyk, J. 2007. Tomotherapy as a tool in image-guided radiation therapy (IGRT): theoretical and technological aspects, Biomedical Imaging and Intervention Journal 3(1): e16. https://doi.org/10.2349/biij.3.1.e16

Yasunaga, H.; Ide, H.; Imamura, T.; Ohe, K. 2007. Price disparity of percutaneous coronary intervention devices in Japan and the United States in 2006, Circulation Journal 71(7): 1128-1130. https://doi.org/10.1253/circj.71.1128 
Gleb DONIN is a Research Assistant in the Department of Biomedical Technology at Czech Technical University in Prague. He holds an engineer's degree at speciality "Biotechnical and medical devices and systems" from Bauman Moscow State Technical University (2002-2008). He has worked as an engineer at the laboratory of the information and technical support of the monitoring of medical devices (since 2006) and as a head of that laboratory (2011-2012) at Russian Scientific Research and Testing Institute for Medical Engineering. He is currently a $\mathrm{PhD}$ candidate in Biomedical and Clinical Technology at the Czech Technical University in Prague (2012-now). His research interests include health technology management, health technology assessment and medical device regulation.

Miroslav BARTÁK is a Lecturer and Research Fellow at the Faculty of Social and Economic Studies, Jan Evangelista Purkyně University in Ústí nad Labem, Czech Republic. He holds PhD in Public and Social Policy (2008). He is also involved in working group Health economics at Faculty of economics of the Technical University Dresden, Germany. His research interests include health economics, international comparison of health systems, health policy and public health. He is an author and co-author of four books and about twenty papers in scientific journals, conference proceedings and book chapters.

Peter KNEPPO worked for the Metra Blansko Company in the Czech Republic, later in the Institute of Measurement Science, Slovak Academy of Sciences as Senior Research Scientist and was promoted to the Scientific Director. As a Technical Director at the Chirana Prema Company he took a leading role in development and implementation of new medical devices, and served as a General Director of the Slovak Institute of Metrology, Bratislava, Slovakia in global metrological system. As a Professor, he teaches courses on biomeasurement, modelling and metrology at the Slovak Technical University in Bratislava, Technical University in Košice, Trencin University in Trencin and Czech Technical University in Prague. He was elected as the member of the Slovak and of the former Czechoslovak Academy of Sciences, Honorary Member of the former Czechoslovak Society of Biomedical Engineering, the pastchairman of the IMEKO TC-13 "Measurements in Medicine and Biology", the pastpresident of the Slovak Society of Biomedical Engineering and the Fellow of the International Academy of Biomedical Engineering. He has published 7 books and more than 300 other publications dealing with measurements and modelling in medicine and metrology thus continuing in research of biomedical measurement and medical instrumentation, especially measurement and modelling of the cardiac electric and magnetic fields, medical metrology and health technology management. 